\title{
Asbestotic radiological abnormalities among United States merchant marine seamen
}

\author{
I J Selikoff, Ruth Lilis, Gayle Levin
}

\begin{abstract}
There has been limited information concerning the prevalence of radiologically evident parenchymal and pleural fibrosis consistent with prior exposure to asbestos among merchant marine seamen, despite the wide use of asbestos in ship construction until the late 1970 s and subsequent exposure of seamen to the asbestos that had been installed. A total of 3324 chest radiographs (1985-7) of long term United States seamen were reviewed. One third $(34 \cdot 8 \%)$ had parenchymal or pleural abnormalities, or both (ILO classification); pleural changes were predominant. Abnormalities increased with longer duration from onset of shipboard exposure (as defined by first year at sea). The prevalence of asbestotic changes was greater among seamen who had served in the engine department $(391 / 420 ; 42 \cdot 5 \%)$ compared with seamen in other departments, including deck $(301 / 820 ; 36.6 \%)$, steward $(278$ I $981 ; 28 \cdot 4 \%$ ), or with service in multiple departments $(167 / 541 ; 30.9 \%)$. Since many vessels, particularly those built before 1978, contain asbestos materials, appropriate engineering controls (including complete removal, if possible) are required as well as appropriate medical surveillance for those who served aboard such ships.
\end{abstract}

The striking reports of asbestos associated disease in shipyards in $1968^{12}$ were consistent with wide use of asbestos in vessels. ${ }^{3}$ Much less was known about hazards that might exist as a result of subsequent exposure of seamen to the asbestos that had been installed.

There were, nevertheless, some indications that this could be a problem. Merewether, in the annual

Division of Environmental and Occupational Medicine, Department of Community Medicine, Mount Sinai School of Medicine of the City University of New York, New York, 10029-6574, USA

I J Selikoff, R Lilis, G Levin report of the Chief Inspector of Factories for 195\% had noted that the removal of old heat insulating lagging was hazardous and that adequate ventilation aboard ship was "rarely possible."4 This was' emphasised at the ILO International Symposium ono Health Risks in Shipbuilding and Ship Repairing in 1971, where urgent repair in the engine rooms of ships at sea was regarded as a "most hazardous procedure." 5

In American ships asbestos materials had largely been used in bulkhead systems in living spaces 0 insulation of hot water and steam piping, and boilers and tanks in machinery spaces. Asbestos insulationp was also used in and around machinery spaces, usings block insulation and asbestos cement. The latter has also been used for steam, hot water piping, and tanks United States Maritime Commission studies noted that "Long after the vessel has been put to sea flaking and cracking due to ship motions and vibra윽 tions are suspected of releasing asbestos into the surrounding space," and "In the course of a voyage it is not unusual for crewmen to repair pipes, pipe flanges, or valve leaks and this generally means a tear-目 down situation. We must assume then that machin- 3 ery and piping asbestos insulation . . . affect not only 3 the shipyard worker, but the crew as well under variety of conditions." 6

It was estimated that all vessels delivered before 1975 had extensive asbestos insulating materiaP aboard, and that most vessels delivered between 1975 and 1978 might have some asbestos in the form of insulating cement on machinery casings, although the total amount of asbestos bearing materials had been greatly reduced. No quantitative data were published concerning the levels of exposure to asbes- $\omega$ tos fibre associated with these different conditions.

Asbestos associated disease had been reported을 among seamen. The first report in 1918 on radiological abnormalities after exposure to asbestos ${ }^{-}$ included a marine fireman. ${ }^{7}$ Subsequently, instances $\frac{0}{-}$ of parenchymal fibrosis, ${ }^{8}$ pleural plaques, ${ }^{9}$ pseudo- $\frac{\vec{D}}{\mathbb{D}}$ tumours, ${ }^{1011}$ lung cancer, ${ }^{12}{ }^{13}$ and mesothelioma ${ }^{14-22} \stackrel{\square}{\square}$ were published.

Nevertheless, no substantial information on how important the problem might be in population terms $\delta$ was available until Jones and his colleagues addedo 
substantially to our awareness of the problem in $1984 .^{23}$ They found pleural plaques in asymptomatic marine engineers given annual chest $x$ ray examinations in their Union Diagnostic Clinic in New Orleans; asbestotic pleural abnormalities were present in $27 \%$ for the longest membership category (more than 35 years) and they were aware of instances of mesothelioma in this group of men.

\section{Present study}

Random instances of parenchymal and pleural fibrosis consistent with the effects of exposure to asbestos had been seen in merchant seamen in our hospital in the late 1970s and early 1980s. The individuals had been members of a major maritime union and inquiry was made of the union regarding the possibility of an appropriate large scale survey, particularly of their long term seafarer members, to ascertain how common asbestos associated disease might be among them. At the time, unfortunately, such a study could not be initiated. The situation changed in 1985, however, when an experienced legal specialist in maritime occupational health compensation problems began to explore the question, using union membership lists of about 10000 active and retired merchant marine seamen. To determine whether large scale detailed asbestos health examinations of these workers would be warranted, it was considered desirable to first obtain information on the prevalence of $x$ ray changes consistent with the effect of exposure to asbestos (parenchymal or pleural fibrosis, or both). It was appreciated that disease could be present in the absence of radiological abnormality, but it was equally understood that the prevalence of such changes could provide useful information on the overall question of asbestos associated disease among merchant marine seamen and could help guide the development of more detailed epidemiological or clinical studies.

All individuals on the membership lists were invited to come for chest $x$ ray examination; approximately half did so. We were asked to review and evaluate the films. When the radiographs were submitted for evaluation, name, date of birth, social security number, first year at sea, last year at sea, department category aboard ship (engine, steward, deck), and date of $x$ ray examination were provided. All had served aboard United States flag vessels, the majority having sailed on many different ships over the years, both ocean going and on the Great Lakes.

Interpretation of the films was undertaken, using the 1980 ILO classification. In addition to study of parenchymal and pleural fibrosis, attention was directed to the detection of other important abnormalities (cancer, mesothelioma, or tuberculosis, for example) and if detected or suspected notification of the merchant marine seamen and his/her physician was arranged.

\section{Materials and methods}

Altogether $3488 x$ ray films were reviewed without information on age, job category, year of onset of merchant marine service, or total number of years at sea, at hand. The films were interpreted according to the International Classification of Radiographs of Pneumoconioses by an experienced B reader. ${ }^{24}$

A total of 102 films of poor technical quality were classified as being "unreadable." Chest $x$ ray films of 62 women had been included; because of their small number these films were excluded from the analysis.

Statistical analysis of abnormalities on chest $x$ ray films was then performed (GL); prevalence rates of radiological abnormalities by job category and years from onset of merchant marine service were of particular interest.

The three major job categories were comprised of similar numbers of subjects; 920 had been categorised as "engine," 823 as "deck," and 981 as "steward." In addition 541 had worked in more than one of the foregoing departmental categories. This group was considered as potentially having been exposed to multiple sources (table 1).

Duration from onset of exposure to asbestos aboard ship was compared for the different job categories. The mean value (and standard deviation) for "years at sea" (duration of potential exposure aboard ship) was similar for the three major job classifications $(27 \cdot 8,28 \cdot 1$, and $28 \cdot 2$ years). This long mean duration of exposure indicates that most seafarers examined had been at sea for more than 20 years (table 2).

Table 1 Job classification of 3324 United States merchant marine seaman

\begin{tabular}{lrr}
\hline & No & $\%$ \\
\hline Total chest x ray films & 3488 & \\
Film quality inadequate & 102 & $2 \cdot 9$ \\
Female & 62 & $1 \cdot 8$ \\
Departments: & & \\
Engine & 920 & $27 \cdot 7$ \\
Deck & 823 & $24 \cdot 8$ \\
Steward & 981 & $29 \cdot 5$ \\
Multiple & 541 & $16 \cdot 3$ \\
Not known & 59 & $1 \cdot 8$ \\
Total & 3324 & \\
\hline
\end{tabular}

Table 2 Duration of potential asbestos exposure in 3324 United States merchant marine seamen

\begin{tabular}{|c|c|c|c|}
\hline \multirow[b]{2}{*}{ Department } & \multirow[b]{2}{*}{ No } & \multicolumn{2}{|c|}{ Years at sea } \\
\hline & & Mean (y) & $S D$ \\
\hline $\begin{array}{l}\text { Deck } \\
\text { Engine } \\
\text { Steward } \\
\text { Multiple } \\
\text { Not known }\end{array}$ & $\begin{array}{c}823(24.8 \%) \\
920(27 \cdot 7 \%) \\
981(29.5 \%) \\
541(16.3 \%) \\
59(1.8 \%)\end{array}$ & $\begin{array}{l}27 \cdot 8 \\
28 \cdot 1 \\
28 \cdot 2 \\
25 \cdot 9 \\
29 \cdot 3\end{array}$ & $\begin{array}{r}11 \cdot 8 \\
10 \cdot 8 \\
9 \cdot 8 \\
11 \cdot 4 \\
8 \cdot 6\end{array}$ \\
\hline Total & 3324 & $27 \cdot 7$ & $11 \cdot 0$ \\
\hline
\end{tabular}


Onset of exposure had occurred before 1939 in almost $11 \%$ of those whose chest $x$ ray films were reviewed; however, most $(49.5 \%)$ had started their employment in the decade $1940-9$; only $8.1 \%$ had joined the merchant marine in $\mathbf{1 9 7 0}$ or later (tables 3 and 4).

Table 3 Years of onset of potential asbestos exposure in 3324 United States merchant marine seamen

\begin{tabular}{lcc}
\hline \multicolumn{3}{c}{ Onset of merchant marine service } \\
First year at sea & No & $\%$ \\
\hline$\leq 1939$ & 359 & $10 \cdot 8$ \\
$1940-9$ & 1646 & 49.5 \\
$1950-9$ & 488 & $14 \cdot 7$ \\
$1960-9$ & 423 & $12 \cdot 7$ \\
$\geq 1970$ & 268 & 8.1 \\
Not known & 140 & $4 \cdot 2$ \\
Total & 3324 & \\
\hline
\end{tabular}

Table 4 Duration of merchant marine service in 3324 United States merchant marine seamen

\begin{tabular}{rllllll}
\hline \multicolumn{9}{c}{ Last year at sea } \\
\cline { 3 - 7 } No & $\begin{array}{l}\text { First year } \\
\text { at sea }\end{array}$ & $1940-9$ & $1950-9$ & $1960-9$ & $\geq 1970$ & $\begin{array}{l}\text { Not } \\
\text { known }\end{array}$ \\
\hline 359 & $\leq 1939$ & 2 & 4 & 123 & 226 & 4 \\
1646 & $1940-9$ & 5 & 17 & 417 & 1188 & 19 \\
488 & $1950-9$ & - & 3 & 36 & 445 & 4 \\
423 & $1960-9$ & - & - & 18 & 400 & 5 \\
268 & $\geq 1970$ & - & - & - & 265 & 3 \\
140 & Not known - & - & - & - & 50 \\
3324 & & & & & & 85 \\
\hline
\end{tabular}

\section{Results}

In $2167(65.2 \%)$ of the total of 3324 films reviewed no abnormalities consistent with pneumoconioses, as categorised in the ILO classification, were found (table 5).

Small irregular opacities in the lung parenchyma, with profusion $1 / 0$ or higher as the only abnormality, were found in 329 cases $(9.9 \%)$. In another 227 $(6.8 \%)$ small parenchymal opacities and pleural abnormalities (pleural thickening, pleural plaques, with or without calcification) were present. In 601 cases $(18 \cdot 1 \%)$ pleural abnormalities were the only radiological changes (table 5). Altogether, parenchymal or pleural abnormalities, or both, consistent with the effect of exposure to asbestos were detected in $1157(34.8 \%)$ of 3324 merchant marine seamen (tables 5 and 6).

The highest prevalence of radiological abnormalities was found among those classified as having been exposed in the engine department (42.5\%) whereas the lowest prevalence $(28.4 \%$ ) was found for the steward category (table 7). This gradient is consistent with available information on intensity of exposure to asbestos aboard ship; the highest exposures occurred in the engine room where most
Table 5 Radiological findings in 3324 United States merchant marine seamen

\begin{tabular}{lrr} 
& No & \multicolumn{1}{c}{$\%$} \\
\hline Parenchyma $(\geq 1 / 0)$ & 329 & 9.9 \\
Pleural changes only & 601 & $18 \cdot 1$ \\
Parenchymal and pleural changes & 227 & 6.8 \\
Total parenchymal changes & 556 & 16.7 \\
Total pleural changes & 828 & 24.9 \\
Total abnormalities & 1157 & 34.8 \\
Absence of radiologically detectable & & \\
abnormalities consistent with pneumoconioses & 2167 & 65.2
\end{tabular}

*Including changes limited to small opacities $0 / 1$ or to costophrenic angle blunting (not categorised as abnormal).

Table 6 Radiological findings in 3324 United States merchant marine seamen 1985-7

\begin{tabular}{|c|c|c|}
\hline & \multicolumn{2}{|c|}{$x$ Ray abnormalities } \\
\hline & No & $\%$ \\
\hline $\begin{array}{l}\text { Parenchyma only: } \\
1 / 0 \text { and higher } \\
0 / 1^{\star}\end{array}$ & $\begin{array}{l}329 \\
346\end{array}$ & $\begin{array}{r}9.9 \\
10.4\end{array}$ \\
\hline $\begin{array}{l}\text { Pleura only: } t \\
\text { Circumscribed only } \\
\text { Diffuse only } \\
\text { Circumscribed and diffuse only }\end{array}$ & $\begin{array}{r}324 \\
37 \\
14\end{array}$ & $\begin{array}{l}9 \cdot 7 \\
1 \cdot 1 \\
0 \cdot 4\end{array}$ \\
\hline $\begin{array}{l}\text { Other: } \\
\text { Diaphragm only } \\
\text { Costophrenic angle only }\end{array}$ & $\begin{array}{l}64 \\
45\end{array}$ & $\begin{array}{l}1.9 \\
1.4\end{array}$ \\
\hline $\begin{array}{l}\text { Multiple abnormalities: } \\
\text { Parenchyma ( } 1 / 0 \text { and higher) and pleura } \\
\text { Pleural fibrosis with two or more sites }\end{array}$ & $\begin{array}{l}227 \\
162\end{array}$ & $\begin{array}{l}6.8 \\
4.9\end{array}$ \\
\hline
\end{tabular}

Table 7 Job classification category and radiological findings in 3324 United States merchant marine seamen

\begin{tabular}{lccccc}
\hline & \multicolumn{5}{c}{$x$ Ray abnormality } \\
\cline { 3 - 6 } Department & $\begin{array}{c}\text { No of } \\
\text { seamen }\end{array}$ & None & $\%$ & Abnormal & $\%$ \\
\hline Deck & 823 & 522 & 63.4 & 301 & 36.6 \\
Engine & 920 & 529 & 57.5 & 391 & 42.5 \\
Steward & 981 & 702 & 71.6 & 279 & 28.4 \\
Multiple & 541 & 374 & 69.1 & 167 & 30.9 \\
Not known & 59 & 40 & 67.8 & 19 & 32.2 \\
Total & 3324 & 2167 & 65.2 & 1157 & 34.8 \\
\hline
\end{tabular}

*Changes limited to small opacities $0 / 1$ or $\mathrm{CP}$ angle blunting not categorised as abnormal.

asbestos insulation material was in place and where repair was most frequently required.

The relation between duration from onset of exposure and prevalence of parenchymal and pleural abnormalities was also investigated for each of the job categories (tables 8-12).

The prevalence of small opacities did not significantly increase after the duration from onset of exposure had reached 10-19 years; the overall prevalence of parenchymal abnormalities was $9.9 \%$. Pleural abnormalities showed an appreciably dif- 
Table 8 Years from onset of exposure and radiological abnormalities consistent with effects of asbestos

\begin{tabular}{|c|c|c|c|c|c|c|c|c|c|}
\hline \multirow[b]{3}{*}{ Years from onset } & \multirow[b]{3}{*}{ No of seamen } & \multicolumn{8}{|c|}{ All departments combined } \\
\hline & & \multicolumn{2}{|c|}{$\begin{array}{l}\text { Parenchymal changes } \\
\text { only }\end{array}$} & \multicolumn{2}{|c|}{$\begin{array}{l}\text { Pleural changes } \\
\text { only }\end{array}$} & \multicolumn{2}{|c|}{$\begin{array}{l}\text { Parenchymal and } \\
\text { pleural changes }\end{array}$} & \multicolumn{2}{|c|}{ Total abnormal } \\
\hline & & No & $\%$ & No & $\%$ & No & $\%$ & No & $\%$ \\
\hline $\begin{array}{l}0-9 \\
10-9 \\
20-9 \\
30-9 \\
240 \\
\text { Unknown } \\
\text { Total }\end{array}$ & $\begin{array}{r}147 \\
298 \\
374 \\
777 \\
1588 \\
140 \\
3324\end{array}$ & $\begin{array}{r}6 \\
32 \\
36 \\
83 \\
157 \\
15 \\
329\end{array}$ & $\begin{array}{r}4 \cdot 1 \\
10 \cdot 7 \\
9 \cdot 6 \\
10 \cdot 7 \\
9.9 \\
10 \cdot 7 \\
9 \cdot 9\end{array}$ & $\begin{array}{r}8 \\
24 \\
63 \\
148 \\
336 \\
22 \\
601\end{array}$ & $\begin{array}{r}5 \cdot 4 \\
8 \cdot 1 \\
16 \cdot 8 \\
19 \cdot 0 \\
21 \cdot 2 \\
15 \cdot 7 \\
18 \cdot 1\end{array}$ & $\begin{array}{r}1 \\
14 \\
24 \\
59 \\
119 \\
10 \\
227\end{array}$ & $\begin{array}{l}0.7 \\
4.7 \\
6.4 \\
7.6 \\
7.5 \\
7 \cdot 1 \\
6.8\end{array}$ & $\begin{array}{r}15 \\
70 \\
123 \\
290 \\
612 \\
47 \\
1157\end{array}$ & $\begin{array}{l}10.2 \\
23.5 \\
32.9 \\
37.3 \\
38.5 \\
33.6 \\
34.8\end{array}$ \\
\hline
\end{tabular}

Table 9 Years from onset of exposure and radiological abnormalities consistent with effects of asbestos

\begin{tabular}{|c|c|c|c|c|c|c|c|c|c|}
\hline \multirow[b]{3}{*}{ Years from onset } & \multirow[b]{3}{*}{ No of seamen } & \multicolumn{8}{|c|}{ Engine department } \\
\hline & & \multicolumn{2}{|c|}{$\begin{array}{l}\text { Parenchymal changes } \\
\text { only }\end{array}$} & \multicolumn{2}{|c|}{$\begin{array}{l}\text { Pleural changes } \\
\text { only }\end{array}$} & \multicolumn{2}{|c|}{$\begin{array}{l}\text { Parenchymal and } \\
\text { pleural changes }\end{array}$} & \multicolumn{2}{|c|}{ Total abnormal } \\
\hline & & .No & $\%$ & No & $\%$ & No & $\%$ & No & $\%$ \\
\hline $\begin{array}{l}0-9 \\
10-9 \\
20-9 \\
30-9 \\
\geq 40 \\
\text { Unknown }\end{array}$ & $\begin{array}{r}42 \\
77 \\
116 \\
238 \\
411 \\
36\end{array}$ & $\begin{array}{r}2 \\
7 \\
13 \\
28 \\
31 \\
4\end{array}$ & $\begin{array}{r}4 \cdot 8 \\
9 \cdot 1 \\
11 \cdot 2 \\
11 \cdot 8 \\
7 \cdot 5 \\
11 \cdot 1\end{array}$ & $\begin{array}{r}3 \\
6 \\
23 \\
59 \\
113 \\
8\end{array}$ & $\begin{array}{r}7 \cdot 1 \\
7 \cdot 8 \\
19 \cdot 8 \\
24 \cdot 8 \\
27 \cdot 5 \\
22 \cdot 2 \\
\end{array}$ & $\begin{array}{r}0 \\
5 \\
8 \\
27 \\
49 \\
5\end{array}$ & $\begin{array}{r}- \\
6.5 \\
6.9 \\
11.3 \\
11.9 \\
13.9\end{array}$ & $\begin{array}{r}5 \\
18 \\
44 \\
114 \\
193 \\
17\end{array}$ & $\begin{array}{l}11.9 \\
23.4 \\
37.9 \\
47.9 \\
47.0 \\
47.2\end{array}$ \\
\hline Total & 920 & 85 & $9 \cdot 2$ & 212 & 23.0 & 94 & $10 \cdot 2$ & 391 & $42 \cdot 5$ \\
\hline
\end{tabular}

Table 10 Years from onset of exposure and radiological abnormalities consistent with effects of asbestos

\begin{tabular}{|c|c|c|c|c|c|c|c|c|c|}
\hline \multirow[b]{3}{*}{ Years from onset } & \multirow[b]{3}{*}{ No of seamen } & \multicolumn{8}{|c|}{ Deck department } \\
\hline & & \multicolumn{2}{|c|}{$\begin{array}{l}\text { Parenchymal changes } \\
\text { only }\end{array}$} & \multicolumn{2}{|c|}{$\begin{array}{l}\text { Pleural changes } \\
\text { only }\end{array}$} & \multicolumn{2}{|c|}{$\begin{array}{l}\text { Parenchymal and } \\
\text { pleural changes }\end{array}$} & \multicolumn{2}{|c|}{ Total abnormal } \\
\hline & & No & $\%$ & No & $\%$ & No & $\%$ & No & $\%$ \\
\hline $\begin{array}{l}0-9 \\
10-19 \\
20-29 \\
30-39 \\
\geq 40 \\
\text { Unknown }\end{array}$ & $\begin{array}{r}30 \\
95 \\
96 \\
165 \\
412 \\
25\end{array}$ & $\begin{array}{r}0 \\
10 \\
10 \\
22 \\
54 \\
1\end{array}$ & $\begin{array}{r}\overline{10 \cdot 5} \\
10 \cdot 4 \\
13 \cdot 3 \\
13 \cdot 1 \\
4 \cdot 0\end{array}$ & $\begin{array}{r}2 \\
7 \\
18 \\
38 \\
81 \\
4\end{array}$ & $\begin{array}{r}6 \cdot 6 \\
7 \cdot 4 \\
18 \cdot 8 \\
23.0 \\
19 \cdot 7 \\
6 \cdot 0\end{array}$ & $\begin{array}{r}0 \\
5 \\
10 \\
8 \\
29 \\
2\end{array}$ & $\begin{array}{r}- \\
5 \cdot 3 \\
10 \cdot 4 \\
4 \cdot 8 \\
7 \cdot 0 \\
8.0\end{array}$ & $\begin{array}{r}2 \\
22 \\
38 \\
68 \\
164 \\
7\end{array}$ & $\begin{array}{r}6 \cdot 6 \\
23 \cdot 2 \\
40 \cdot 0 \\
41 \cdot 2 \\
39 \cdot 8 \\
28 \cdot 0\end{array}$ \\
\hline Total & 823 & 97 & $11 \cdot 8$ & 150 & $18 \cdot 2$ & 54 & 6.4 & 301 & $36 \cdot 6$ \\
\hline
\end{tabular}

Table 11 Years from onset of exposure and radiological abnormalities consistent with effects of asbestos

\begin{tabular}{|c|c|c|c|c|c|c|c|c|c|}
\hline \multirow[b]{3}{*}{ Years from onset } & \multirow[b]{3}{*}{ No of seamen } & \multicolumn{8}{|c|}{ Steward department } \\
\hline & & \multicolumn{2}{|c|}{$\begin{array}{l}\text { Parenchymal changes } \\
\text { only }\end{array}$} & \multicolumn{2}{|c|}{$\begin{array}{l}\text { Pleural changes } \\
\text { only }\end{array}$} & \multicolumn{2}{|c|}{$\begin{array}{l}\text { Parenchymal and } \\
\text { pleural changes }\end{array}$} & \multicolumn{2}{|c|}{ Total abnormal } \\
\hline & & No & $\%$ & No & $\%$ & No & $\%$ & No & $\%$ \\
\hline $\begin{array}{l}0-9 \\
10-19 \\
20-29 \\
30-39 \\
\geq 40 \\
\text { Unknown }\end{array}$ & $\begin{array}{r}31 \\
56 \\
100 \\
246 \\
517 \\
31\end{array}$ & $\begin{array}{r}2 \\
7 \\
5 \\
23 \\
48 \\
1\end{array}$ & $\begin{array}{r}6 \cdot 5 \\
12 \cdot 5 \\
5 \cdot 0 \\
9 \cdot 3 \\
9 \cdot 3 \\
3 \cdot 2\end{array}$ & $\begin{array}{r}3 \\
4 \\
11 \\
35 \\
90 \\
5\end{array}$ & $\begin{array}{l}9 \cdot 7 \\
7 \cdot 1 \\
11 \\
14 \cdot 2 \\
17 \cdot 4 \\
16 \cdot 1\end{array}$ & $\begin{array}{r}1 \\
2 \\
6 \\
12 \\
24 \\
0\end{array}$ & $\begin{array}{l}3 \cdot 2 \\
3 \cdot 6 \\
6 \cdot 0 \\
4 \cdot 9 \\
4 \cdot 6 \\
-\end{array}$ & $\begin{array}{r}6 \\
13 \\
22 \\
70 \\
162 \\
6\end{array}$ & $\begin{array}{l}19 \cdot 4 \\
23 \\
22 \\
28 \cdot 5 \\
31 \cdot 3 \\
19 \cdot 4\end{array}$ \\
\hline Total & 981 & 86 & $8 \cdot 8$ & 148 & $15 \cdot 1$ & 45 & $4 \cdot 6$ & 279 & $28 \cdot 4$ \\
\hline
\end{tabular}


Table 12 Years from onset of exposure and radiological abnormalities consistent with effects of asbestos

\begin{tabular}{|c|c|c|c|c|c|c|c|c|c|}
\hline \multirow[b]{3}{*}{ Years from onset } & \multirow[b]{3}{*}{ No of seamen } & \multicolumn{8}{|c|}{ Multiple departments } \\
\hline & & \multicolumn{2}{|c|}{$\begin{array}{l}\text { Parenchymal changes } \\
\text { only }\end{array}$} & \multicolumn{2}{|c|}{$\begin{array}{l}\text { Pleural changes } \\
\text { only }\end{array}$} & \multicolumn{2}{|c|}{$\begin{array}{l}\text { Parenchymal and } \\
\text { pleural changes }\end{array}$} & \multicolumn{2}{|c|}{ Total abnormal } \\
\hline & & No & $\%$ & No & $\%$ & No & $\%$ & No & $\%$ \\
\hline $\begin{array}{l}0-9 \\
10-19 \\
20-29 \\
30-39 \\
\geq 40 \\
\text { Unknown }\end{array}$ & $\begin{array}{r}42 \\
69 \\
60 \\
121 \\
229 \\
20\end{array}$ & $\begin{array}{r}2 \\
8 \\
8 \\
10 \\
23 \\
5\end{array}$ & $\begin{array}{r}4.8 \\
11 \cdot 6 \\
13 \cdot 3 \\
8 \cdot 3 \\
10 \cdot 0 \\
25 \cdot 0\end{array}$ & $\begin{array}{r}0 \\
7 \\
9 \\
14 \\
48 \\
3\end{array}$ & $\begin{array}{l}\overline{10} \cdot 1 \\
15 \\
11 \cdot 6 \\
21 \cdot 0 \\
15 \cdot 0\end{array}$ & $\begin{array}{r}0 \\
2 \\
0 \\
12 \\
16 \\
0\end{array}$ & $\begin{array}{l}\overline{2.9} \\
\overline{9.9} \\
7.0 \\
-\end{array}$ & $\begin{array}{r}2 \\
17 \\
17 \\
36 \\
87 \\
8\end{array}$ & $\begin{array}{r}4 \cdot 8 \\
24 \cdot 6 \\
28 \cdot 3 \\
29 \cdot 8 \\
38 \cdot 0 \\
40 \cdot 0\end{array}$ \\
\hline Total & 541 & 56 & $10 \cdot 4$ & 81 & $15 \cdot 0$ & 30 & $5 \cdot 5$ & 167 & 30.9 \\
\hline
\end{tabular}

ferent trend: their prevalence consistently increased with duration from onset of exposure; it reached the highest level, $21.2 \%$, in those with more than 40 years from onset of exposure.

Since pleural abnormalities had a prevalence almost twofold higher than that of parenchymal abnormalities, their effect on the prevalence of all radiological abnormalities (parenchymal and pleural) resulted in a consistent increase with duration from onset of exposure. The prevalence rate for all radiological asbestos related abnormalities (pleural or parenchymal or both) reached its highest level $(38.5 \%)$ in those with more than 40 years from onset of exposure.

Thus radiological abnormalities on chest $x$ ray films of merchant marine seamen were found with higher prevalence for job classifications with higher exposure to asbestos (engine room); the prevalence rates also increased with duration from onset of exposure. The relation with duration of exposure was stronger for pleural changes than for parenchymal abnormalities.

\section{Discussion}

Exposure to asbestos of merchant marine seamen was of concern because of the large amounts of asbestos materials known to have been used in the past in ship building. Asbestos induced adverse effects in shipyard workers, including interstitial pulmonary fibrosis, pleural fibrosis, mesothelioma, and an increased incidence of lung cancer, are now well known and have been reported from most ship building areas in the world. Insulation with asbestos containing products was particularly extensive in engine rooms. It is appreciated that, with time, unavoidable deterioration of asbestos insulation products may occur in all types of buildings, including schools. That this would result in airborne asbestos contamination in the relatively confined spaces of ships was to be expected but the effects of the resulting exposure on merchant marine seamen had not been evaluated in a comprehensive manner.

Review of a large number of chest $x$ ray films of merchant marine seamen with long duration from onset of work on ship was undertaken to assess the risk of developing asbestos induced parenchymal interstitial fibrosis or pleural fibrosis, or both, as a result of exposure to asbestos on board ship. The 을 results indicate an overall prevalence of radiological abnormalities of over $34 \%$. Pleural abnormalities were found with a higher prevalence than parenchymal changes. The prevalence of radiological abnormalities was highest in those with departmental classification "engine." There was a consistent increase of total asbestos related abnormalities with years from onset of exposure to asbestos; this trend was present for pleural abnormalities, although it was not consistently present for parenchymal abnormalities alone and did not result in a steady increase in the prevalence of interstitial pulmonary fibrosis.

Among the 3324 chest $x$ ray films of merchant marine seamen, 13 cases of lung cancer were detected; all but two of these patients had started employment before 1949 (5.5 lung cancer cases per 1000) (table 13).

Data are available indicating that merchant marine seamen in the United Kingdom have significant adverse mortality experience, including an approximate doubling of total deaths (all causes), total cancer deaths, and deaths from lung cancer (for categories "deck, engine room hands, bargemen, light tenders, and boatmen; deck, engineering and radio officers, and pilots, ship; and foremen, ships, lighters, and other vessels). ${ }^{25}$ This experience was not specific for shipboard exposure to asbestos, although it may be relevant to such a hazard; the effects of exposure to asbestos on mortality patterns of merchant marine seamen remain to be established by appropriate epidemiological mortality studies.

Table 13 Other significant lung disease among 3324 United States merchant marine seamen, 1985-7

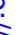
N . (a) 产 . 2 을 음 프. స 
The identification of a risk of exposure to asbestos as a result of this study and other similar investigations ${ }^{26}$ makes it imperative that exposure to asbestos on ships be eliminated or greatly reduced through adequate engineering controls, including removal of all asbestos in place. Such measures would prevent additional exposure of currently employed seamen and avoid exposure of new generations of merchant marine seamen. It would be advantageous that those exposed in the past be offered appropriate medical care and surveillance.

Requests for reprints to: Dr I J Selikoff, Box 1059, Mount Sinai School of Medicine, 1 Gustave Levy Place, New York, NY 10029-6574.

1 Harries PG. Asbestos hazards in naval dockyards. Ann Occup Hyg 1968;11:135-45.

2 Stumphius J, Meyer PB. Asbestos bodies and mesothelioma. Ann Occup Hyg 1968;11:283-93.

3 Harries PG. Asbestos dust concentrations in ship repairing: a practical approach to improving asbestos hygiene in naval dockyards. Ann Occup Hyg 1971;14:241-54.

4 Merewether ERA. Annual report of the Chief Inspector of Factories for the year 1956. London: HMSO, 1958 (Cmnd. 329).

5 Selikoff IJ. Disease prevention in asbestos insulation work. In: International symposium on safety and health in shipbuilding and ship repairing, Helsinki, 1971. Geneva: International Labour Office, 1972. (Occupational safety and health series No 27.)

6 Polland LD. The American merchant marine and the asbestos environment. Washington: Maritime Administration Office of Ship Construction, US Department-of Commerce, 1979:12-4.

7 Pancoast HK, Miller TG, Landis HRM. A roentgenologic study of the effects of dust inhalation upon the lungs. American Journal of Roentgenology 1918;5:129-38.

8 Case records of the Massachusetts General Hospital. Weekly clincopathological exercises. Case 73-1961. Chronic pneumonitis and marked pleuritis. Left upper lobe: asbestosis. New Engl J Med 1961;265:745-51.

9 Roberts WC, Ferrans VJ. Pure collagen plaques on the diaphragm and pleura. Gross, histologic and electron microscope observations. Chest 1972;61:357-460.

10 Blesovsky A. The folded lung. Br J Dis Chest 1986;60:19-22.

11 Shin MS, Ho KJ, Sears NJ. Cicatrizing pleuritis with rounded atelectasis associated with asbestos exposure. Alabama Medicine 1984;54:12-7.

12 Martischnig KM, Newall DJ, Barnsley WC, Cowan WK, Feinmann EL, Oliver E. Unsuspected exposure to asbestos and bronchial carcinoma. $\mathrm{Br} M e d J$ 1977;i:746-9.

13 Gottleib MS, Stedman RB. Lung cancer in shipbuilding and related industries in Louisiana. South Med J 1979;72: 1099-1101.

14 Dalquen P, Dabbert AF, Hinz I. Mesothelioma of the pleura. An analysis of 119 cases. Prax pneumol 1969;23:547-58.

15 Stossel HG, Dalquen P, Carstens U. Pleural mesotheliomas in dockers. Fortschr Geb Roentgenstr 1972;116:41-5.

16 de Lajartre M, Rembeaux A, Michaud JC, de Lajartre AY, Dupon H, Cornet E. Mesotheliome pleural diffus et amiante. Etude de 38 cas operes. Ouest Medicine 1976;29:615-21.

17 de Lajartre M, Cornet E, Corroler J, et al. Etude clinique et professionelle de 54 mesotheliomes pleuraux diffus. Rev $\mathrm{Fr}$ Mal Resp 1976;4:63-74.

18 Gaucher P, de Lajartre M. Mesotheliomes: donnees socioprofessionnelles. Archives des Maladies Professionnelles de Medecine du Travail de Sécurité Sociale 1977:38:347-57.

19 Donaldson JC, Kaminiski DB, Elliot RC, Walsh TE, Newly JG. Psammoma bodies in pleural fluid associated with mesothelioma: case report. Milit Med 1979;144:476-9.

20 Lam WK, Zung TM, Ma PL, So SY, Mok CK. First report of asbestos-related diseases in Hong Kong. Trop Geogr Med 1983;35:225-9.

21 Martensson G, Hagnar B, Lettergren L. Diagnosis and prognosis in malignant pleural mesothelioma: a prospective study. Eur J Respir Dis 1984;65:169-78.

22 Solomons K. Malignant mesothelioma-clinical and epidemiological features. A report of 80 cases. $S$ Afr Med J 1984;66: 407-12.

23 Jones RN, Diem JE, Ziskind NM, Rodriguez M, Weill $H$. Radiographic evidence of asbestos effects in American marine engineers. J Occup Med 1984;26:281-4.

24 International Labour Office. The ILO international classification of radiographs of pneumoconioses. Geneva: ILO, 1980. (Occupational health and safety series No 22.)

25 Office of Population Census and Surveys. Supplement on occupational mortality. London: OPCS, 1985:table 0.0.43.

26 Velonakis EG, Tsorva A, Tzonou A, Trichopoulos D. Asbestos related chest $x$ ray changes in Greek merchant marine seamen. Am J Ind Med 1989;15:511-6.

Accepted 24 July 1989 